Nota Bene - This version is an accepted manuscript, provided by the author as a means to ensure timely dissemination of scholarly work on a non-commercial basis. Please cite as published:

Lazarus, E. (2020) Money beats the ocean. Nat Sustain 3, 7-8. https://doi.org/10.1038/s41893-0190463-3

\title{
MONEY BEATS THE OCEAN
}

Eli Lazarus discusses Pulizer-Prize-winning author Gilbert Gaul's new book on coastal risk.

The Geography of Risk: Epic Storms, Rising Seas, and the Cost of America's Coasts Gilbert M. Gaul Sarah Chrichton Books (2019)

Thirty years ago, scholars David Godschalk, David Brower, and Timothy Beatley published Catastrophic Coastal Storms: Hazard Mitigation and Development Management (Duke University Press, 1989), a policy-focused academic monograph on coastal disasters in the southeastern United States. "The policy problem of coping with coastal disasters is not new," they wrote. "But the scope of the problem [emphasis theirs] has grown as more urban development has taken place...so that exposures of large amounts of property and human populations to hurricane threats are no longer rare and isolated events."

Decades later, that problem, and its scope, are still growing. In The Geography of Risk: Epic Storms, Rising Seas, and the Cost of America's Coasts (Sarah Chrichton Books, 2019), writer Gilbert Gaul tours many of the same hurricane alleys of the US Atlantic and Gulf Coasts that Godschalk and his colleagues examined. Twice winner of the Pulitzer Prize for journalism, Gaul turns his formidable investigatory attention to describing how coastal development from New Jersey to Texas has evolved in ways that all but provoke disaster.

A native of New Jersey, Gaul devotes much of his book to describing the modern history of Long Beach Island, the geographical heart of the New Jersey shore, as an allegory of American coastal development. While he constructs a careful narrative from historical records and interviews, there is a lingering sense that Gaul's own recollections of the Jersey Shore, then and now, haunt the subtext. The modest, blue-collar vacation bungalows that multiplied over the southern reaches of Long Beach Island between the 1930s and 1960s - called "Shapiro shacks", not unkindly, after their developer, Morris Shapiro - have been replaced by comparatively immodest million-plus-dollar second homes that crowd the edges of their lots. In his original vision of his developments, Shapiro left room at the shoreline for dunes. Now, a visitor to the oceanfront row has to squint and imagine where those dunes would have been.

Gaul seems especially unsettled by the frenzies of coastal redevelopment that pile in behind every damaging weather event. In New Jersey, those frenzies began after the Ash Wednesday Storm of 1962. "Hurricanes and violent nor'easters have come to serve as market-clearing devices," Gaul explains, "weeding out older, more vulnerable homes while freeing space for the next wave of development". Gaul bares the irony of hurricanes razing beach towns as though tilling for a new crop of larger houses. (My colleagues and I quantified similar patterns of "building back bigger" in an article for this journal last December: [link: Lazarus et al., 2018].) Synthesising "lessons from Camille, Fredric, and Alicia," hurricanes that barrelled into the US Gulf Coast in 1969, 1979, and 1983, respectively, Godschalk and his colleagues concluded that "a hurricane does not change the essential character of a locality in terms of its attitude toward the use of public policy to intervene in the private development market." Borrowing from the parlance of speculators, they called the same phenomenon "hurricane renewal".

Not only does the "build-destroy-rebuild cycle" persist at enormous public expense, Gaul reports, but post-disaster reconstruction has an insidious way of exacerbating wealth disparities. From the Atlantic to the Gulf, Gaul maps out historically sleepy beach towns - Long Beach Island, the Outer Banks, Folly Beach, Mexico Beach, Dauphin Island, the Galveston Peninsula - where collars have bleached from blue to white after major storms. Bigger beach houses and ever-riskier 
Nota Bene - This version is an accepted manuscript, provided by the author as a means to ensure timely dissemination of scholarly work on a non-commercial basis. Please cite as published:

Lazarus, E. (2020) Money beats the ocean. Nat Sustain 3, 7-8. https://doi.org/10.1038/s41893-019$\underline{0463-3}$

development is not the inevitable march of economic progress. Rather, the trend is heavily dependent on loopholes in federal disaster-relief policy. Propped up by federally subsidized insurance and buffered from the ocean by federally financed hazard-protection programmes, coastal properties getting built and rebuilt in harm's way are, in Gaul's view, the enigmatic signature of moral hazard run amok. Moral hazard is a situation in which a person does not bear the full cost of a decision they make. In a federal insurance programme, for example, every taxpayer in the country effectively contributes toward guaranteeing a select number of properties in the event of a disaster - even if those properties sit in an established hazard zone, as many federally insured properties do.

Alongside insurance is the quandary of federal coastal protection - which, again, benefits a small number of owners, relative to the total number of properties nationwide. When Gaul quotes the late Jim Mancini, long-time mayor of Long Beach Island, that "money beats the ocean", Mancini was stumping for a federally funded beach nourishment programme to widen the township's eroding beaches with imported sand - an engineering practice that has been the dominant form of coastal hazard mitigation in the US since the 1960s. Gaul explains the complicated machinations by which the federal government still pays the lion's share - and in many cases the entirety - of beach nourishment works for coastal towns with erosion problems.

In one sense, "money beats the ocean" implies the power of well-funded engineering to overwhelm the forces of nature. A more idealistic view is that substantial, targeted investment in a portfolio of adaptation measures - from property buy-outs and building moratoriums to dune and wetland rehabilitation - are ways to make hurricanes and sea-level rise less disastrous. But in another sense, Gaul shows that private development interests continue to steamroll any notion of accommodating and adapting to the natural dynamics of coastal environments. Gaul's geography of risk is a direct consequence of money beating the ocean.

Despite the broad reach of the title, Gaul keeps to American shores. Aside from the brief mention of some Dutch engineering consultants, the book offers no international view of coastal development patterns. But private property rights are so fundamental to the American creation myth that, when concentrated at the coast, they create a distinctly American problem. The continental scale of the US coastline makes an otherwise national problem international news.

Perhaps because Gaul is a surfer, a Jersey Shore local of a particular tribe, his book is more elegiac than others published in the same vein. His work shares more in common with the curated story-telling of Elizabeth Rush's Rising: Dispatches from the New American Shore (Milkweed Editions, 2018) than, for example, the popular-science reportage of Jeff Goodell's The Water Will Come: Rising Seas, Shrinking Cities, and the Remaking of the Civilized World (Black Inc., 2018) or the true-crime flair of Michael Grunwald's The Swamp: The Everglades, Florida, and the Politics of Paradise (Simon \& Schuster, 2006). Perhaps Gaul's "meditation on the question of risk" carries an undertone of grief because he describes a problem with which he is intimately familiar but to which he sees no clear answer. The same solutions that Godschalk and his colleagues laid out in 1989 are just as true today: de-escalating American coastal risk will require a suite of proactive policy measures and credible, toothy enforcement; and hazard mitigation is pointless without coordinated land-use planning to complement it. Such reform also remains as out of reach as it did then.

"The probability of a killer hurricane striking a coastal area is not reducible by human action," Godschalk and his colleagues wrote. "The likelihood of massive erosion from sea-level rise allowing a hurricane surge to inundate a coastal area is tied to forces we do not know how to control. What we can manage is how we build on the coast." Gaul echoes that warrant, but with 
Nota Bene - This version is an accepted manuscript, provided by the author as a means to ensure timely dissemination of scholarly work on a non-commercial basis. Please cite as published:

Lazarus, E. (2020) Money beats the ocean. Nat Sustain 3, 7-8. https://doi.org/10.1038/s41893-019$\underline{0463-3}$

scepticism. When American ideals - and thus coastal real estate markets - will ultimately absorb that lesson is still anyone's guess. In the meantime, betting is open. 